\title{
Anthologie de la poésie haïtienne contemporaine, éd. James Noël
}

Alba Pessini

\section{(2) OpenEdition}

1 Journals

\section{Édition électronique}

URL : http://journals.openedition.org/studifrancesi/5463

DOI : 10.4000/studifrancesi.5463

ISSN : 2421-5856

Éditeur

Rosenberg \& Sellier

\section{Édition imprimée}

Date de publication : 1 décembre 2016

Pagination : $578-579$

ISSN : 0039-2944

\section{Référence électronique}

Alba Pessini, «Anthologie de la poésie haïtienne contemporaine, éd. James Noël », Studi Francesi [En ligne], 180 (LX | III) | 2016, mis en ligne le 01 janvier 2017, consulté le 18 septembre 2020. URL : http:// journals.openedition.org/studifrancesi/5463 ; DOI : https://doi.org/10.4000/studifrancesi.5463

Ce document a été généré automatiquement le 18 septembre 2020.

\section{(c) $($ ) $(9)$}

Studi Francesi è distribuita con Licenza Creative Commons Attribuzione - Non commerciale - Non opere derivate 4.0 Internazionale. 


\title{
Anthologie de la poésie haïtienne contemporaine, éd. James Noël
}

\author{
Alba Pessini
}

\section{RÉFÉRENCE}

Anthologie de la poésie haïtienne contemporaine, dirigée et présentée par James NOËL, Paris, Points, 2015, 558 pp.

1 James Noël, n'a de cesse de nous régaler avec ses recueils personnels (le dernier en date Le pyromane adolescent, paru d'abord chez Mémoire d'encrier en 2013 et ensuite au Seuil dans la collection Points en 2015, contient également Le sang visible du vitrier), avec l'énergie débordante qu'il insuffle aux collaborateurs de la revue intranQu'îllité dont il est le «maître d'œuvre» depuis 2012 et qui en est aujourd'hui à son quatrième numéro qui vient tout juste de sortir (juin 2016). L'Anthologie de la poésie haïtienne contemporaine qu'il a coordonnée est un énième témoignage de sa volonté tenace de contribuer à la diffusion des lettres haïtiennes. Ce volume de 558 pages réunit 73 poètes qui ont chacun livré à James Noël «cinq de leurs plus beaux poèmes», un choix qui engage donc le poète et laisse le «metteur en page» libre de toute critique. Dans les quatre pages intitulées «Un choix pour nous», Noël nous éclaire sur la démarche qui l'a conduit à cette anthologie, sa «singularité [...] tient au fait qu'elle forme un tapis volant de subjectivités éclatées» (p.11). Nous y côtoyons les grands noms de la poésie haïtienne en partant du doyen René Depestre ou encore Gérald Bloncourt, Anthony Phelps, Georges Castera, Frankétienne, Gary Klang, Lyonnel Trouillot, Joël Des Rosiers, Rodney Saint-Éloi, que nous ne nous lassons pas de lire et de relire, cependant nous y faisons aussi de belles découvertes, de jeunes, voire très jeunes poètes (le dernier en date recensé est Fabian Charles né en 1993) qui entrent en poésie et qui partagent avec leurs prédécesseurs une quête, un combat, un langage, un imaginaire qu'ils déclinent en vers.

2 À la fin de l'anthologie, juste avant la section qui abrite de brèves notices biobibliographiques concernant les auteurs, les quelques pages en guise de «Repères» 
sous la plume de James Noël et Rodney Saint-Éloi posent les jalons pour nous permettre à nous, lecteurs, de mieux appréhender la place de la poésie dans cet espace complexe et fascinant qu'est Haïti. Bien que la poésie ait toujours été, par le passé, le genre privilégié auquel faisaient appel les poètes en herbe qui se destinaient à une carrière plus ou moins prometteuse, il est vrai aussi qu'elle représente aujourd'hui une sorte de défi pour la jeunesse qui tente d'avancer sur les traces de ses idoles: «Le même besoin d'exister par la poésie anime les jeunes du pays, qui mettent dans les mots tout l'espoir que leur refuse l'État» (p. 531). Noël et Saint-Éloi nous expliquent comment la poésie a réussi à s'imposer et surtout les efforts qui ont été faits (maisons d'éditions, journaux, revues, bibliothèques, centres culturels, sites web) pour qu'elle participe et se mêle au quotidien par les passeurs qui s'en chargent, interprètes, chansonniers, musiciens comme «l'incontournable Boulot Valcourt qui met en musique des poèmes de Syto Cavé» (p.532). Chanteurs, rappeurs et slameurs empruntent à la poésie pour nourrir leur créativité et la poésie se prête bien à cet échange: «Une diversité de langages et de registres suburbains donne toute la vitalité à la poésie haïtienne contemporaine (p. 534). 